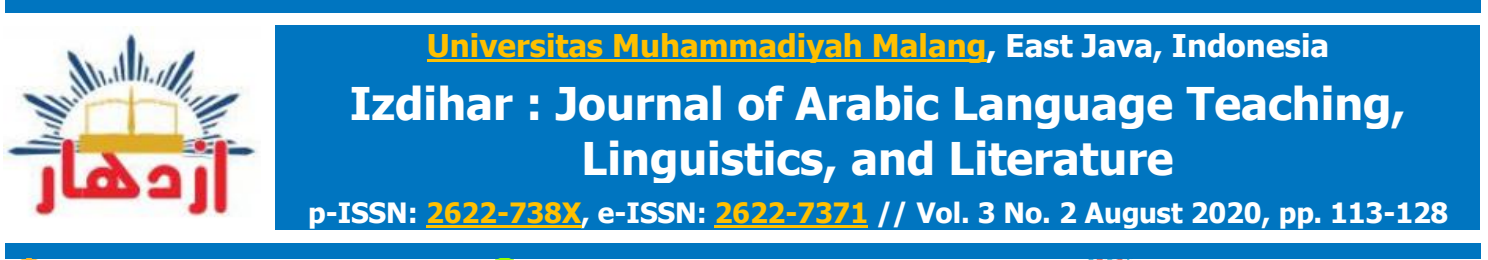

d.

https://doi.org/10.22219/jiz.v3i2.12337 htw

\title{
Amplification and Description Techniques in the Translation of Arabic Phrases in Matan Al-Ghayah wa Al-Taqrib
}

\author{
Wiji Lestaria,1, Yoyo Yoyo ${ }^{b, 2}$, Abdul Razif Zainic,3 \\ a,bUniversitas Ahmad Dahlan, Indonesia \\ 'Islamic International University College Selangor, Malaysia \\ 1wijilestari02313@gmail.com, 2yoyo@bsa.uad.ac.id*, ${ }^{3}$ abdulrazif@kuis.edu.my
}

\section{ARTICLE INFO}

Article History:

Submitted: $31 / 05 / 2020$

Revised: $16 / 07 / 2020$

Accepted: $24 / 08 / 2020$

Published: $31 / 08 / 2020$

\section{*Corresponding}

Author:

Name: Yoyo

Email:

yoyo@bsa.uad.ac.id

\section{ABSTRACT}

The translation from Arabic into Indonesian on the Islamic field has its long history. However, researches on the subject are a little bit rare. Therefore, the study of the item using a modern approach is required. This research described the use of amplification and descriptions techniques in the translation of Arabic phrases in the reading of Matan alGhayah wa al-Taqrib by Ahmad Ma'ruf Asrori. Besides, this paper aimed to describe the quality of the text that is seen from the aspect of readability. This research used a qualitative analysis combined with a quantitative data approach. The data were selected and classified based on procedures of translation techniques. The results showed that based on the amplification techniques there were 35 data in Matan al-Ghayah wa al-Taqrib found 35 which can be divided into four Arabic phrases based as follows: 1) 'atfy phrases are 12 data, 2) idhafy phrases are 13 data, 4) syibhu al-jumlah phrases are 5 data, and 5) adjective phrases are 5 data. Whereas in the description technique, the researchers found 31 data divided into five Arabic phrases based on their constituent elements, namely the 'atfy phrase 12 data, idhafy phrase 12 data, 'adady phrase 3 data, syibhu al-jumlah phrase 3 data, and adjective phrase 2 data. From the translation quality, it showed that the use of these two techniques could be seen from the assessment of the readability aspects of 42 respondents. It rated $52 \%$ high readability on the amplification technique, and $56 \%$ high readability on the description technique. It means that the translator used more of these two techniques frequently rather than other techniques. It assumed that amplification and description techniques are much more applicable in the translation of Arabic books into Indonesian due to its acceptance of the cultural dimension of the targeted language.

Copyright (c) 2020, Lestari et al

This is an open access article under the CC-BY-SA license

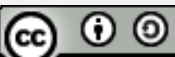

Amplification and Description Technique; Arabic Language Phrase; Aspect of Readability

تصف هذه الدراسة استخدام أسلوب التضخيمة والوصف في ترجمة التركيب اللغوى في قراءة كتاب متن الغاية والتقربب للكاتب أحمد معروف التراف أسروري. علاوة على ذلك، تهدف هذا البحث إلى وصف جودة النص الذي يتم رؤيته من جانب قابلية القراءة. يستخدم هذا البحث البحث طريقة

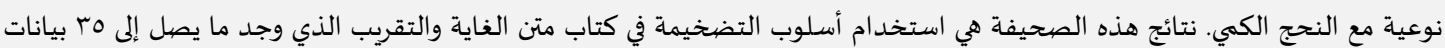

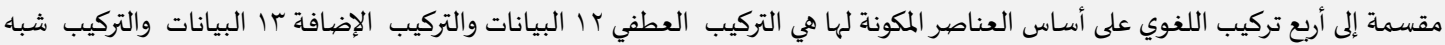

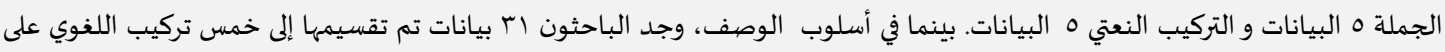

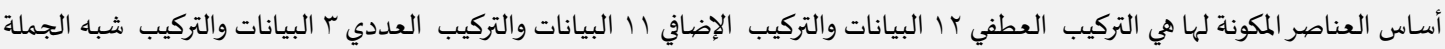

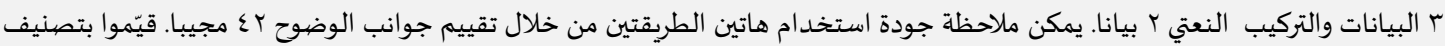

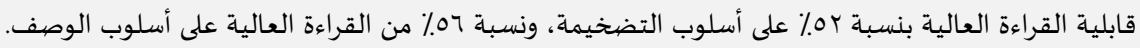




\section{INTRODUCTION}

The translation is an activity of transferring meaning from the source language to the target language by paying attention to the semantic structure of the source language to the target language and the purpose that must be transferred properly (Angelone, 2010). Therefore, a translator should have language acquisition (Fitriyah \& Fauzi, 2020). Typically, reading includes understanding as an activity of producing a message or message of a source language with an equivalent closest to the recipient's writing, both meaning and style. A translator must be talented in choosing the equivalent so that the resulting script is easy to read and easily understood by the reader (Baker, 2018). If someone is skilled in choosing word management, the manuscript produced as if not the result of translation (Pym, 2013).

In Indonesian, the need for translation results is very high, especially in religious Fiqh books. Fiqh is considered as the most important discipline among all branches of Islamic theology (van Bruinessen, 2008). In Islamic Boarding School or Pesantren, figh has a significant place among all Islamic subjects (van Bruinessen, 2008). Figh books, which are, in general, written in Arabic, provides santri (the students of Islamic Boarding School) to understand Arabic text in a proper manner (Murtadlo, 2015). However, the mastery of Arabic among traditional santri, in particular, is only passive due to the lack of ability to understand Arabic for professional purposes (Fatoni, 2019; Yoyo \& Mukhlis, 2019).

Among the many religious books that discuss figh is the translation of the Matan al-Ghayah wa al-Taqrib of Abu Syuja' Ahmad bin Husain wich is than translated by Ahmad Ma'ruf Asrori (2010) into Indonesian titled "Ringkasan Fikih Islam: Terjemah Matan Ghoyah wat Taqrib." Matan al-Ghayah wa al-Taqrib contains summaries of fiqh, starting from the chapter of thaharah or purification to the chapter of 'itqi or slave liberation. This book is unique due to its wider acceptance of Muslim communities. Besides, this book also contains light comments that can be understood by laypeople (Maulidiyah, Sa'dullah, \& Hasan, 2019). On the other side, this figh book, as one of the Arabic classical Islamic texts, has its authority and highest cultural position due to its use of classical or Arabic fusha (Yoyo, Mukhlis, Thonthowi, \& Ferawati, 2020).

There are many different translations of the Matan al-Ghayah wa alTaqrib, and its forms are also varied. Translation techniques are needed by translators to solve these obstacles (Sprung \& Jaroniec, 2000). In this case, Ahmad Ma'ruf Asrori indeed used techniques to translate. Translation technique is a method used to divert messages from SL (Source Language) to TL (Target Language), applied at the level of words, phrases, clauses, and sentences (Ordudari, 2007). According to Molina and Albir (2002), translation techniques 
are used as a procedure to analyze and classify how the translation is in place and can be applied to various lingual units. Among the Arabic translation techniques are amplification and description techniques.

Amplification Technique is a technique that introduces detailed information that is not contained in the SL text, namely exploitation or exploitation (Canepa, Cohen \& Tang, 2015). Meanwhile, this technique carried out to clarify an ellipsis expression, avoid impatience or ambiguity, and add connectors. In other words, this translation is a translation that adds detailed information that not contained in the source-language text (Molina \& Albir, 2002). Additions to this technique are the only information that is used to help convey the message or understanding of the reader and must not change the word in the source language text.

The next technique used to analyze a translation is the description technique. Description techniques are translation techniques applied by replacing a term or phrase with a description of its form and function (Hansen, 2010; Toury, 1982). In other words, this technique sends the meaning of the source language text into the target language in combination freely. Different from amplification, description techniques explicitly implied information. But in practice, these techniques provide information and also the impact in a translation.

There were several similar studies on the subject. First, research conducted by Ahmad Muthohir Arif (2019) with the title "Analysis of Grammatical Structures of the Translation of KH Basori Alwi in the Book of Matan al-Ghayah wa al-Taqrib." In this study, he analyzed the structure of translation in terms of syntax and criticism of translation works. Second, the research conducted by Muhammad Arkom (2010) in "Reduction Strategy in the Translation of the Book of Al-Mawa'idu Al-Usfuriyah by Muhammad bin Abu Bakar Al-Usfuri (Analysis of Theory and Critical Translations)." According to him, the translation in this book was not consistent in using the translation method. He also criticized the way the translators reduced the meaning of the source language.

Other researches were conducted by Riyal Mahmudin (2015) from UIN Syarif Hidayatullah titled "Fuad Kauma Translation Method Against the Book of Nashaihul Ibad by Sheikh Nawawi Al-Bantani." Based on his survey, he found that the method of translation is literal translations. The translator's obedience can illustrate it to the grammar of texts, sources, phrases, and so forth. Research conducted by Nauval Fitriah (Fitriah, 2017) from UIN Syarif Hidayatullah was under the title "Translation of the Book of Al-Misbah Fi Bayani Ahkami Al-Nikah by KH. Hasyim Ash'ari". This research described the implementation and translation strategies, which emphasized on a semantic method and strategies applied in the translation. The last study conducted by Ahmad Mustain (Mustain, 2015) from UIN Sunan Kalijaga in "Problems of Translating Taqrib into 
Indonesian Santri of Komplek IJ Al-Masyhuriyah Ponpes Al-Munawwir Krapyak Yogyakarta." The study concluded that many students still stuck with errors in reading the text due to the lack of mastery of Arabic, both in its vocabularies and grammar.

Based on the previous studies, the authors offered to use amplification and description techniques in Indonesian translation of Matan al-Ghayah wa alTaqrib by focusing on the four Arabic phrases which include idhafy, 'atfy, syibhu al-jumlah, and the na'at man'ut phrase. Although the study of the translation of Matan al-Ghayah wa al-Taqrib has already been conducted before, the criteria and elements used by the authors are completely different. Therefore, the authors found that this study had an academic contribution on the way it explains the use of the two translation techniques in the translation of Arabic phrases. Besides, the study explored the reason why the translator decided to choose one method and ignored another one.

\section{METHOD}

The paper used a qualitative method. The qualitative method is a research method is used to examine the condition of objects, producing descriptive data in the form of written or oral words where the researcher as the core means (Polkinghorne, 2005). Data collection techniques are carried out by triangulation or combined ones (Jentoft \& Olsen, 2019; Moran-Ellis et al., 2006). Data collection was done by collecting data related to the problem under study. The reason for the researchers to use descriptive qualitative methods was to find out the extent of the use of Molina and Albir (2002) translation techniques and its influence on the quality of the translation of the Arabic phrases found in Matan al-Ghayah wa al-Taqrib.

Meanwhile, to analyze the quality of the translation, the researchers distributed questionnaires to 42 respondents. The criteria for respondents were students: 1) Arabic Language and Literature Department in Universitas Ahmad Dahlan, Yogyakarta Indonesia 2) in the $5^{\text {th }}$ semester of the academic year 20172018,3 ) have not taken the subject of translation courses, and 4) mastery of the targeted language (Indonesian).

\section{RESULTS \& DISCUSSION}

\section{Amplification Technique}

The use of amplification technique in the translation of the book Matan alGhayah wa al-Taqrib as a whole is 36 data which can be divided into four Arabic 
phrases based on its constituent elements. The phrases are the idhafy phrase, 'atfy phrase, syibhu al-jumlah phrase, and the na'at man'ut phrase. There were describe four samples regarding the use of amplification techniques in Arabic phrases using simple random sampling techniques and its analysis in the translation of the book Matan al-Ghayah wa al-Taqrib.

The phrase of 'Atfy

'Atfy phrase it is also called as phrasal coordination. In the phrasal coordination element takes the same inflection as the first element (Badawi, Carter, \& Gully, 2004).

Source language: وغسل جميع الابوال والارواث واجب

Target language: Membasuh semua (yang terkena) air kencing dan kotoran (manusia atau hewan) itu adalah wajib. [Washing all (affected) urine and faces (human or animal) is mandatory].

In line with the notion of amplification technique, which is a translation technique that explicitly or paraphrases information that is implied in the source language, so in this case, the researchers found the use of amplification techniques in the phrase 'atfy الأرواث which has meaning in the dirt. The word الأرواث in the dictionary means "dung, shit" (Al-Munawwir, 1997). It is called the phrase 'atfy because in this phrase it has the noun الأرواث with the noun الابواث and then this element is connected with the letter 'ataf. Then the translator adds detailed information that is not present in the source language text, which is human and animal worlds. This aims to make it clear that what is included in the meaning of dung is not only human feces but also animal dung. So that in this translation can be understood to wash all those affected by urine and feces, either human or animal is mandatory. Therefore, in addition to providing information that is not in the source language, amplification techniques also help provide clarity that can prevent ambiguity. This addition is only used to help convey the message and understanding of the reader without changing the word in the source language text.

\section{The phrase of Syibhu al-Jumlah}

Syibhu al-jumlah or compound adjectives is equivalent to hyphenated pairs in Western languages, are created in modern Arabic only by juxtaposition, commonly also with a hyphen (Badawi et al., 2004). 
Source language : الدمّ الواجبة بالاخصيار

Target language: Denda (dam) yang wajib (dibayar) karena terkepung (oleh musuh atau jalannya terhalang oleh penodong) [fines (dam) that must be (paid) for being surrounded (by the enemy or the road is blocked by the mugger)].

The word إحصيار fi'll, which means "to from the حصر - يحصر - حصرا comes surround, surround, encircle" (Al-Munawwir, 1997). The phrase syibhu al-jumlah is called because this phrase is based on the letter $ب$ and is followed by the noun الخصيار. In this case, the amplification technique is used to make explicit information implicit, namely clarification in the context of the discussion in the translation of beleaguered meanings. This meaning is then clarified by providing an explanation sense following the context of the debate, namely "by the enemy, or the way is blocked by the mugger" and not surrounded by animals.

\section{The phrase of Idhafy}

The idhafy phrase or annexation means 'making a thing very close to another,' often referred to as status constructus and the genitive construction, is the collocation of two elements, usually both nouns, in a fixed and inseparable unit (Badawi et al., 2004).

Source language : وصاحب الجبائر يمسح عليها وتيمّم ويصلى

Target language: Orang yang menggunakan pembalut (perban karena luka atau lainnya) boleh mengusap balutannya (ketika berwudhu), tetapi kemudian harus bertayammum dan (barulah boleh) melakukan shalat. [People who use bandages (bandages due to wounds or other) may wipe the dressing (when performing ablution), but then must perform tayammum and (only then) perform prayers].

Based on the data, the researchers found the use of amplification techniques in the phrase idhafy صاحب الجبائر, which means "People who use pads (bandages due to injuries or others)". The word صاحب is a isim fa'il of صحب which means "to accompany" (Al-Munawwir, 1997) and the word الجبائر in the dictionary means "bracelet" (Al-Munawwir, 1997). Called the phrase idhafy because this phrase has the noun (N1) صاحب as mudhaf and noun (N2) الجبائر

as the mudhaf ilaih. In this text, the translator paraphrases by adding an element of clarity that is the equivalent of another word to the description of the bandages and bandages. It is intended that the reader is not mistaken in understanding the word sanitary. Generally, in Indonesia, the term sanitary napkin is an object 
that is used when women are menstruating. This paraphrase aims to prevent ambiguity or impropriety in this sub-discussion. Also, the translator provides a parable cause of using pads such as wounds or others as information and the addition of connectors.

The phrase of Na'at Man'ut

In the traditional Arab analysis, adjectival clauses qualifying indefinite nouns are taxonomically the same as adjectives, and both are termed as shiffah or na'at, while clauses qualifying definitive nouns are treated as adjuncts and thus termed as shillah or man'ut/attachment (Badawi et al., 2004).

Source language: والدماء الواجبة في الاحرام

Target language: Denda-denda yang wajib (dibayar sebab terjadinya pelanggaran) di dalam melakukan ihram. [Obligatory fines (paid for violations) in making Ihram].

In line with the notion of amplification techniques, namely translation techniques that explicitly or paraphrase information that is implied in the source language, so in this case, the researchers found the use of amplification techniques on the phrase na'at man'ut الدماء الواجبة. The word الدماء in the dictionary has the meaning "blood" (Al-Munawwir, 1997), and the word الواجبة has the meaning "mandatory, permanent, must" (Al-Munawwir, 1997). It is called the man'ut na'at phrase because it is formed from the noun (man'ut) الدماء as the central element and is followed by the adjective (na'at) الواجبة. In this phrase, there is an explicit meaning, which is the translation of "compulsory fines" to "paid for violations." Aside from being information, this addition is intended to make explicit information that the context in this discussion is a fine that must be paid for violations not because they are surrounded or mugged by the enemy. This addition is only as information to help deliver messages in the source language without changing the meaning of the source language.

Table 1. Amplification Techniques

\begin{tabular}{|c|c|c|c|}
\hline No & Phrase & Amount & Percentage \\
\hline 1 & 'Atfy & 13 & $37 \%$ \\
\hline 2 & Syibhu al-Jumlah & 12 & $35 \%$ \\
\hline 3 & Idhafy & 5 & $14 \%$ \\
\hline 4 & Na'at Man'ut & 5 & $14 \%$ \\
\hline & Total & 35 & $100 \%$ \\
\hline
\end{tabular}


Based on Table 1, the use of amplification techniques in the translation of Matan al-Ghayah wa al-Taqrib found as many as 35 data, which divided into four Arabic phrases. The phrases are idhafy phrases, atfy phrases, syibhu al-jumlah phrases, and man'ut na'at phrases. The two phases are commonly found in the text i.e., 'atfy and syibhu al-jumlah. It is because the nature of Arabic phrases its self that tends to have such structures.

\section{Description Technique}

The use of description techniques in the translation of the book Matan alGhayah wa al-Taqrib as a whole is 33 data divided into five Arabic phrases based on their constituent elements, namely 'atfy phrase, idhafy phrase, 'adady phrase, syibhu al-jumlah phrase, and na'at man'ut phrase. The following will describe five samples about the use of description techniques using simple random sampling techniques in Arabic phrases in the translation of Matan al-Ghayah wa al-Taqrib:

The phrase of 'Atfy

Source language: وشرائط الحضانة سبع العقل والحّريّة والدين والعفّة

Target language: Syarat-syarat memelihara anak itu ada tujuh yaitu berakal, merdeka, beragama islam dan iffah (dapat menahan diri dari perbuatanperbuatan buruk ). [There are seven conditions for taking care of a child, that is understanding, freedom, religion (Islam), and iffah (being able to refrain from adverse actions)].

Following the notion of description technique, which is a technique that is applied by replacing a term or expression with a description of form and function, then data number two finds the use of description technique. The purpose of the description technique occurs in the phrase 'atfy والعفّة or translated as iffah. Then the translator adds clarity about the notion of iffah with a more easily understood expression that can refrain from evil deeds. This phrase is included in the phrase group 'atfy because it is a noun العفّة with the noun الدين then this element is associated with the letter 'atf $g$.

If explored deeper etymologically, iffah is a form of masdar from 'affaya'iffu-'iffah which means to keep away from anything that is not lawful and good. Besides, according to Al-Ghazali in terminology, iffah can be interpreted as educating impotence with reason and sharia education. In this case, of course, the translator gives the term iffah in a concrete form without changing the meaning of the source language. 


\section{The phrase Idhafy}

Source language: و ان ملك الأمة المطلّقة بعد ذلك لم تصر أمّ ولد له بالوطء في النكاح

Target language: Jika orang yang menyetubuhi itu memiliki budak perempuan yang ia cerai sesudah disetubuhinya, maka budak perempuan tersebut tidak akan menjadi ummu walad (sebutan untuk budak perempuan yang menjadi ibu dari anak hasil persenggamaan tuannya dengan dirinya tanpa nikah) baginya dengan persetubuhan nikah. [If the person who has intercourse has a slave girl whom he divorced after having sex, then the slave-girl will not be ummu walad (the term for a female slave who is the mother of the child the result of the relationship of her master with hem without marriage) for her with marital intercourse].

Based on the data, the researcher found the use of the description technique in the idhafy phrase أمّ ولد by changing the terms of their position. The word $ّ$ l in the dictionary has the meaning "mother" (Al-Munawwir, 1997) and the word ولد has the meaning "baby boy." The sentence ummu walad is described as being a slave girl who is the mother of a child the result of intercourse with her master without marriage. This explanation is done to make it easier for readers to understand the meaning of ummul walad better. The term is called idhafy because this phrase has the noun (N1) أمّ as mudhaf and noun (N2) ولد as ilaih mudhaf

The phrase of 'Adady

Source language: وعشرون بنت لبون

Target language: 20 ekor binta-labun (unta betina yang sudah waktunya berair susu). [20 Binta-labun (female camels with milk time)].

The next discussion is the use of description techniques in 'adady phrase data. In this number of data, the use of the description technique occurs in the phrase 'adady بنت لبون. Tشرون The word in the dictionary has the meaning "twenty" (Al-Munawwir, 1997) and the name بنت لبون has the meaning "camel two years old" (Al-Munawwir, 1997). In line with the notion of description technique, which is a technique that is applied by replacing a term or expression with a description of form and function, in this case, the translator returns the name بنت by instilling a female camel whose time is milky. In this translator, 
the conclusion can be drawn that the shape of the camel female whose time is watery milk is called the bintu labun. The phrase belongs to the type 'adady because it is a number ('adad) عشرون which is then followed by the noun (ma'dud) بنت لبون.

\section{The phrase of Syibhu al-Jumlah}

Source language : وان أصابها بشبهة فولده منها حرّ

Target language: Jika menyetubuhi dengan wathi syubhat (persetubuhan yang dilakukan karena keliru, di mana perempuan yang disetubuhi itu dikira istri/budaknya ternyata adalah bukan) maka anaknya yang dari budak perempuan itu adalah merdeka. [If intercourse with wathi syubhat (sex made in error, where the woman who is intercourse is thought to be his wife/slave turns out to be not) then his child from the slave girls independent].

The data showed the use of description techniques in the translation of the phrase syibhu al-jumlah بشبهة. The word شبهة in the dictionary means "the same, similar conditions" (Al-Munawwir, 1997). The phrase of syibhu al-jumlah is called because this phrase is based on the letter $\varphi$ and is followed by the noun شبهة. The use of this description technique is marked by an explanation from the wathi subhat, namely "intercourse which was done in error, where the woman who intercourse was mistaken for his wife or slave was not."

The phrase of Na'at Man'ut

Source language : فإذا عدمت العصبات فالمولى المعتق ثمّ عصابته ثم الحاكم

Target language: Jika ashabah-ashabah sudah tidak ada, maka wali jatuh kepada maulal mu'tiq (bekas tuan yang telah memerdekakan), lalu ashabah-ashabahnya, kemudian hakim. [If the ashabah are gone, the trustee falls on the maulal mu'tiq (former master who has set him free), then the ashabah, then the judge].

The data showed that the translator used the description technique in translating the na'at man'ut المولى المعتق, which means "maulal mu'tiq". The word in the dictionary has the meaning " the employer, the owner " (Al-Munawwir, 1997), and the word المعتق has the meaning "liberate" (Al-Munawwir, 1997). The phrase na'at man'ut is called because it is formed from the noun (man'ut) المولى 
as the central element and is followed by the adjective (na'at) المعتق (Kremers, 2003). Then the translator adds the term expression with a description of a more extended form that does not exist in the source language text, that is, the term ex-master who has set free. Therefore, with this explanation, the translation becomes more transparent and more comprehensible even if the reader is among the layman.

Table 2. Description Technique

\begin{tabular}{clcc}
\hline No & Phrase & Amount & Percentage \\
\hline 1 & Phrase 'Atfy & 12 & $39 \%$ \\
\hline 2 & Phrase Idhafy & 11 & $35 \%$ \\
\hline 3 & Phrase 'Adady & 3 & $10 \%$ \\
\hline 4 & Phrase Syibhu al-Jumlah & 3 & $10 \%$ \\
\hline 5 & Phrase Na'at Man'ut & 2 & $6 \%$ \\
\hline & Total & $\mathbf{3 1}$ & $\mathbf{1 0 0 \%}$
\end{tabular}

Overall, the use of description techniques in the translation of Matan alGhayah wa al-Taqrib in Table 2 is as much as 31 data divided into five phrases; 'athfy, idhafy, 'adady, syibhu al-jumlah, and na'at man'ut. As the amplification technique, the 'athfy and idhafy phrases are dominat in number.

\section{Aspects of Readability}

In answering the problem about aspects of readability, the researcher uses the readability aspect theory that was initiated by Nababan (2004). Basically, to assess a work of translation needed parameter assessment of the quality of translation. Among the assessment parameters, there are three aspects of evaluation, namely elements of accuracy, aspects of crime, and issues of readability.

The readability aspect is a term used in the field of translation because every translation will not separate from reading activities. With a high readability value, it can be concluded that the use of description and amplification techniques is the right choice. Vice versa, the low readability value is an indication that the use of techniques and amplification has not been able to convey messages from the source language to the target language accurately. Various factors determine the level of readability of translation results. The readability factor depends on the average length of the sentence, the number of new words, and the grammatical complexity used. Another factor determining the level of readability 
is the use of foreign and regional names, taxa words and sentences, and incomplete sentences. These things can make readability low (Nikolarea, 2002).

Evaluation of the quality of translations on the use of amplification and description techniques is done by distributing questionnaires to respondents. The respondents, in this case, are Students of Arabic Language and Literature at the Universitas Ahmad Dahlan who have criteria 1) Students of Arabic Language and Literature in semester 5, 2) Have taken the translation courses, 3) Mastering the target language (Indonesian). Then the researchers collected 42 questionnaires out of a total of 47 respondents.

\section{Amplification Technique}

Overall, the use of amplification techniques, which are the subject of this study, is translated with high quality. In general, the unevenness of assessment scores arises due to differences in understanding of the information presented. Furthermore, based on the results of the average value in each diagram can be submitted using Figure 1

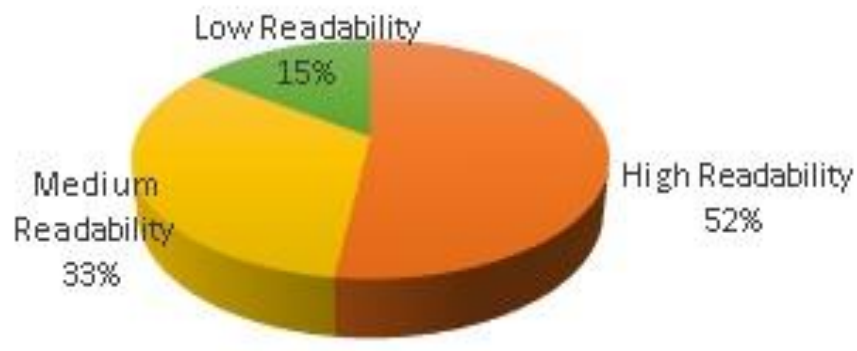

=High Readability = Medium Readability $=$ Low Readability

\section{Figure 1. Readability Aspect of Amplification Techniques}

From 30 analysed data in Figure 1, the use of amplification techniques in the translation of Matan al-Ghayah wa al-Taqrib, on average, have high readability of $52 \%$, moderate readability of $33 \%$, and low readability of $15 \%$. Thus, it can be concluded that the overall use of amplification techniques has a high readability quality. In other words, the information presented in the amplification technique for each phrase can be easily understood by the reader.

\section{Description Technique}

From the data obtained, the use of descriptive techniques that are the subject of this study is also translated with high quality. Differences in assessment scores arise due to respondents' background and their understanding of the 
information presented. Furthermore, based on the results of the average value in each diagram above can be displayed in Figure 2

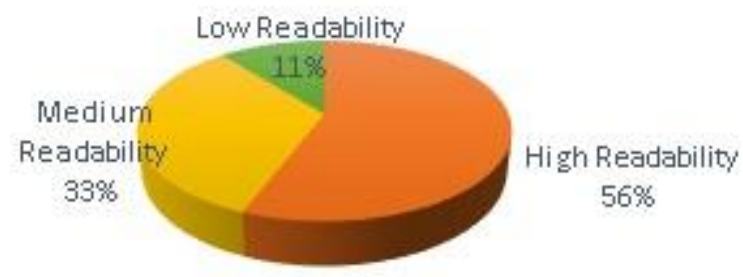

- High Readability = Medium Readability L Low Readability

\section{Figure 2. Readability Aspect of Description Techniques}

From 30 analyzed data in Figure 2, the use of description techniques in the translation of Matan al-Ghayah wa al-Taqrib has high readability with an average of $56 \%$, moderate readability $33 \%$, and low readability $11 \%$. Thus, it can be concluded that the use of description techniques as a whole also has a high quality of readability. In other words, the information presented in the amplification technique is easy to understand. As the material object of this article is a figh text. The authors assumed that the translator preferred to choose the amplification in translation technique because, in general Arabic terms on fiqh subject are much more understandable by the audience. For example, the thaharah is much preferable rather than 'bersuci,' or shalat rather than sembahyang, etc. It is also relevant to the theory of Molina Albir (2002) that amplification technique, in a particular way, adapted the terminologies that are familiar in the targeted language. It is because the terminologies as it has discussed above much more affordable to the local audience. Besides, amplification as narrated by Azmy (2015) is commonly used in the translation because it is in general simplified the translated terms into the targeted language.

\section{CONCLUSIONS}

Analysis of the use of amplification and description techniques in the translation of Arabic phrases in the translation of Matan al-Ghayah wa al-Taqrib gets several conclusions. First, the use of amplification techniques in the translation of Matan al-Ghayah wa al-Taqrib found as many as 35 data which are divided into four phrases namely the phrase of idhafy as many as 13 data, the phrase of 'atfy is 12 data, phrase of syibhu al-jumlah is five data and the phrase na'at man'ut is five data. Second, the use of description techniques in the 
translation of Matan al-Ghayah wa al-Taqrib found 31 data that are divided into five phrases namely the phrase of 'atfy is 12 data, the phrase of idhafy is 11 data, the phrase of 'adady is three data, phrase of syibhu al-jumlah is three data, and the phrase of na'at man'ut is two data. Third, the use of the amplification technique has high readability with a rate of $52 \%$ and the use of description technique has high readability with a rate of $56 \%$. The most commonly found phrase in the amplification technique is the idhafy phrase, while the most frequently found phrase description technique is the phrase of 'atfy. Since the study much more focuses on the aspect of translation technique, the authors suggested further research that pays much more attention to the aspect of the quality of the translation by paying attention to some "unclear" translation while offering some alternative translation based on the targeted language audience.

\section{ACKNOWLEDGMENT}

The authors would like to thank Department of Arabic Language and Literature, Faculty of Islamic Studies, Universitas Ahmad Dahlan for supporting this publication, and also Dr. Abdul Razif Zaini from KUIS, Malaysia, for his generous support to be acted as co-author for this article.

\section{BIBILIOGRAPHY}

Al-Munawwir, A. W. (1997). Kamus Al-Munawwir Arab-Indonesia Terlengkap. Yogyakarta: Pustaka Progressif.

Angelone, E. (2010). Uncertainty, uncertainty management and metacognitive problem solving in the translation task. Translation and Cognition, 15, 1740. DOI: https://doi.org/10.1075/ata.xv.03ang

Arif, A. M. (2019). Analysis of Grammatical Structures of the Translation of KH Basori Alwi in the Book of al-Ghayah wa al-Taqrib. UIN Syarif Hidayatullah.

Arkom, M. (2010). Reduction Strategy in the Translation of the Book of AlMawa 'idu Al-Usfuriyah by Muhammad bin Abu Bakar Al-Usfuri (Analysis of Theory and Critical Trans/ations). UIN Sunan Kalijaga.

Asrori, A. M. (2010). Ringkasan Fikih Islam: Terjemah Matan Ghoyah wat Taqrib. Surabaya: Al-Miftah.

Azmy, R. (2015). Teknik dan Metode Penerjemahan Lirik Lagu AKB48 ke JKT48. Humanis, 12(3), 1-8.

Badawi, E. S., Carter, M., \& Gully, A. (2004). Modern Written Arabic: A Comprehensive Grammar. New Haven and London: Routledge. 
Baker, M. (2018). Translation and Conflict: A Narrative Account. London: Routledge.

Canepa, T. L., Cohen, E. T., \& Tang, A. G. (2015, December 15). Flash translation layer with lower write amplification. Google Patents.

Fatoni, A. (2019). Arabic Learning for Academic Purposes. Izdihar: Journal of Arabic Language Teaching, Linguistics, and Literature, 2(2), 149-164. DOI: https://doi.org/10.22219/jiz.v2i2.10096

Fitriah, N. (2017). Translation of the Book of Al-Misbah Fi Bayani Ahkami A/Nikah by KH. Hasyim Ash'ari. UIN Syarif Hidayatullah.

Fitriyah, T., \& Fauzi, M. F. (2020). Improving Quality of Arabic Translation Course through Jigsaw Cooperative Learning. Izdihar: Journal of Arabic Language Teaching, Linguistics, and Literature, 3(1), 17-30. DOI: https://doi.org/10.22219/jiz.v3i1.11033

Hansen, G. (2010). Integrative Description of Translation Processes. In G. M. Shreve \& E. Angelone (Eds.), Translation and cognition (pp. 189-212). Amsterdam/Philadelphia: John Benjamins Publishing Company.

Jentoft, N., \& Olsen, T. S. (2019). Against the Flow in Data Collection: How Data Triangulation Combined with A 'slow' Interview Technique Enriches Data. Qualitative Social Work, 18(2), 179-193. DOI: https://doi.org/10.1177\%2F1473325017712581

Kremers, J. (2003). Adjectival Agreement in the Arabic Noun Phrase. Proceedings of Console XI. Available Online at Http://Www. Sole. Leidenuniv. NI/Index. Php3.

Mahmudin, R. (2015). Fuad Kauma Translation Method Against the Book of Nashaihul Ibad by Sheikh Nawawi Al-Bantani. UIN Syarif Hidayatullah.

Maulidiyah, S. F., Sa'dullah, A., \& Hasan, N. (2019). Pembelajaran Kitab AlGhayah Wa At-Taqrib Dalam Menguatkan Pemahaman Santri Tentang Thaharah di Pondok Pesantren Thoriqotun Najah Pagentan Singosari Malang. Vicratina: Jurnal Pendidikan Islam, 4(6), 168-174. http://riset.unisma.ac.id/index.php/fai/article/view/3076

Molina, L., \& Hurtado Albir, A. (2002). Translation Techniques Revisited: A Dynamic and Functionalist Approach. Meta: Journal Des Traducteurs/Meta: Translators' Journal, 474), 498-512. DOI: https://doi.org/https://doi.org/10.7202/008033ar

Moran-Ellis, J., Alexander, V. D., Cronin, A., Dickinson, M., Fielding, J., Sleney, J., \& Thomas, H. (2006). Triangulation and Integration: Processes, Claims and Implications. Qualitative Research, 6(1), 45-59. DOI: https://doi.org/10.1177\%2F1468794106058870

Murtadlo, M. (2015). Three Writers of Arabic Texts in Yogyakarta. Heritage of 
Nusantara: International Journal of Religious Literature and Heritage, 3(1), 107-128. DOI: http://dx.doi.org/10.31291/hn.v3i1.22

Mustain, A. (2015). Problems of Translating Taqrib into Indonesian Santri of Komplek IJ Al-Mashhuriyah Ponpes Al-Munawwir Krapyak Yogyakarta. UIN Sunan Kalijaga.

Nababan, M. R. (2004). Strategi Penilaian Kualitas Terjemahan. Jurnal Linguistik BAHASA, 2(1), 54-65. http://jurnal.umtapsel.ac.id/index.php/Linguistik/index

Nikolarea, E. (2002). Performability versus Readability. Translation Journal, 6(4). https://translationjournal.net/journal/22theater.htm

Ordudari, M. (2007). Translation Procedures, Strategies and Methods. Translation Journal, 11(3), 8.

https://translationjournal.net/journal/41culture.htm

Polkinghorne, D. E. (2005). Language and Meaning: Data Collection in Qualitative Research. Journal of Counseling Psychology, 52(2), 137. DOI: https://psycnet.apa.org/doi/10.1037/0022-0167.52.2.137

Pym, A. (2013). Translation skill-sets in a machine-translation age. Meta: Journal Des Traducteurs/Meta: Translators' Journal, 58(3), 487-503. DOI: https://doi.org/10.7202/1025047ar

Sprung, R. C., \& Jaroniec, S. (2000). Translating into Success: Cutting-edge Strategies for Going Multilingual in a Global Age. Amsterdam/Philadelphia: John Benjamins Publishing.

Toury, G. (1982). A Rationale for Descriptive Translation Studies. Dispositio, 719/21), 23-39. https://www.jstor.org/stable/41491224

van Bruinessen, M. (2008). Traditionalist and Islamist pesantrens in contemporary Indonesia. Farish $A$.

https://www.jstor.org/stable/pdf/j.ctt46n10w.12.pdf

Yoyo, Y., \& Mukhlis, A. (2019). Historiography of the Arabic Grammar in Europe: The Legacy of Wright's Arabic Grammar. First International Conference on Progressive Civil Society (ICONPROCS 2019), 212-215. DOI: https://doi.org/10.2991/iconprocs-19.2019.45

Yoyo, Y., Mukhlis, A., Thonthowi, T., \& Ferawati, F. (2020). High Variety Vs Low Variety Culture in the Arabic Language: The Tensions between Fushā and 'Âmiyya in the Contemporary Arab World. Arabi: Journal of Arabic Studies, 5(1), 25-32. DOI: https://doi.org/http://dx.doi.org/10.24865/ajas.v5i1.195 